\title{
Pengamanan Pesan pada Steganografi Citra dengan Teknik Penyisipan Spread Spectrum
}

\author{
SOFIA SAIDAH, NUR IBRAHIM, MOCHAMMAD HALDI WIDIANTO
}

\author{
Universitas Telkom Bandung \\ Email : sofiahsaidahsfi@telkomuniversity.ac.id
}

Received 22 Juli 2019| Revised 9 Agustus 2019| Accepted 22 Agustus 2019

\begin{abstract}
ABSTRAK
Pada studi ini, dilakukan penggabungan metode - metode untuk memperkuat dan meningkatkan sisi keamanan proses pertukaran informasi atau pesan digital. Metode yang digunakan diantaranya adalah metode kriptografi dan metode steganografi. Implementasi pada sistem yang dibangun dilakukan dengan menyandikan pesan pada penerapan metode steganografi citra dalam menyembunyikan pesan tersandi yang dihasilkan ke dalam sebuah citra warna (RGB) dalam domain Discrete Cosine Transform dengan teknik penyisipan Spread Spectrum. Hasil penelitian menunjukan bahwa kualitas dari stego image sangat mirip dengan cover citra yang digunakan, berdasarkan perolehan nilai performansi objektif PSNR diatas $30 \mathrm{db}$ dan subjektif MOS di atas nilai 4.
\end{abstract}

Kata kunci: Steganografi, Discrete Cosine Transform, Spread Spectrum, PSNR, SNR

\begin{abstract}
In this study, a combination of methods was used to strengthen and enhance the security side of the process of exchanging information or digital messages. The methods used include cryptographic methods and steganography methods. The implementation of the system built is done by encoding the message on the application of the image steganography method in hiding the encrypted message generated into a color image (RGB) in the Discrete Cosine Transform domain with the Spread Spectrum insertion technique. The results of the study show that the quality of the stego image is very similar to the cover image used, based on the acquisition of an objective performance value of PSNR above $30 \mathrm{db}$ and subjective MOS above a value of 4 .
\end{abstract}

Keywords: Steganografi, Discrete Cosine Transform, Spread Spectrum, PSNR, SNR 


\section{PENDAhULUAN}

Perkembangan dan kemajuan teknologi komunikasi digital yang pesat, terdapat banyak kemungkinan tindak kejahatan digital yang terus bertambah dan berkembang. Tindak kejahatan digital berupa pencurian maupun penyadapan informasi adalah beberapa isu ancaman keamanan yang harus diamati dan diperhatikan untuk diminimalisir.

Seminar nasional Indonesia Cyber Crime Summit (ICCS) pada tahun 2014, yang diselenggarakan oleh Institut Teknologi Bandung (ITB) didukung oleh PT. Telkom Indonesia, Tbk. menyatakan berdasarkan sumber data dari Kementrian Komunikasi dan Informasi (Kemkominfo) di tahun 2013, Indonesia merupakan negara nomor satu sumber serangan kejahatan cyber dengan tingkat presentasi 38,0\% dimana telah terjadi 42 ribu target serangan setiap harinya (ITB, 2014).

Terkait berdasarkan pokok bahasan di atas, maka aspek-aspek keamanan meliputi kerahasiaan (secrecy) dan orisinilitas informasi (authencity) menjadi hal yang sangat penting untuk tetap terjaga dengan sebaik-baiknya. Adapun beberapa metode keamanan pengiriman informasi atau pesan yang dapat digunakan untuk memperkuat serta meningkatkan sisi keamanan pada proses pertukaran pesan, di antaranya dengan menggunakan metode penyandian pesan yang disebut dengan metode kriptografi dan metode penyembunyian pesan ke dalam sebuah media yang disebut dengan metode steganografi.

Steganografi merupakan seni dan ilmu dalam penyembunyian pesan ke dalam suatu media atau cover, dimana keberadaan pesan tersebut hanya dapat diketahui oleh orang-orang tertentu (Alfian Zakaria, 2015) (Chudasama, 2016). Dibanding kriptografi yang keberadaan pesannya dapat diketahui dengan jelas, steganografi memanfaatkan kelemahan indera manusia agar pesan rahasia tidak dapat diidentifikasi (Alfian Zakaria, 2015). Bagi sebuah komputer, citra merupakan sebuah matriks yang setiap angka pada elemennya merepresentasikan intensitas cahaya pada titik-titik yang disebut pixel (Piksel). Piksel-piksel tersebut membentuk data dari sebuah citra yang biasa kita lihat. Biasanya sebuah citra terdiri dari 1 (grayscale) atau 3 layer (berwarna). Steganografi citra adalah steganografi yang paling populer, yang mana pesan rahasia disisipkan ke dalam citra digital selayaknya menyisipkan noise yang tidak dapat terdeteksi oleh mata manusia (Neil F. Johnson, 2001).

Berdasarkan literatur dan jurnal penelitian sebelumnya, Image Steganography Using Discrete Cosine Transform (DCT) and Blowfish Algorithm (Gunjal \& Jha, 2014) menjelaskan bahwa penggunaan algoritma kriptografi Blowfish dan steganografi citra transformasi kosinus diskrit dapat memperkuat tingkat keamanan dalam pertukaran pesan. Image Steganography Using DCT Technique (Sharma \& Kumar, 2015) menjelaskan bahwa penyembunyian pesan kedalam sebuah citra dengan penggunaan transformasi kosinus diskrit (DCT) dapat memperkecil kemungkinan perubahan yang terjadi pada citra hasil penyembunyian pesan. Spread Spectrum and Discrete Cosine Transform (DCT) Based Steganography (Gouda, 2015) menjelaskan bahwa pada citra hasil penyembunyian pesan dengan penggunaan transfomasi kosinus diskrit (DCT) dan teknik penyisipan Spread Spectrum dihasilkan nilai BER dan PSNR yang lebih baik bila dibandingkan dengan tanpa atau dilakukannya transformasi lain (Hannan dkk, 2017).

Pada studi ini telah dilakukan penelitian, implementasi dan pengujian sistem pada penerapan metode kriptografi dan penerapan metode steganografi citra digital domain Discrete Cosine Transform (DCT) dengan teknik penyisipan Spread Spectrum yang dapat digunakan sebagai variasi model sistem keamanan lainnya. 


\section{Metode Citra}

Metode penerapan steganografi citra memiliki dua buah kawasan (domain) yang dapat digunakan yaitu domain spasial dan domain frekuensi (Sharma \& Kumar, 2015) . Dalam domain spasial, bit-bit pesan disisipkan secara langsung ke dalam intensitas pixel cover citra sedangkan dalam domain frekuensi, bit-bit pesan disisipkan pada pixel cover citra hasil transformasi domain frekuensi yang dilakukan terlebih dahulu. Perbedaan pengaruh penggunaan kawasan (domain) dalam menyisipkan bit-bit pesan dapat mempengaruhi nilai kemiripan dan ketahanan antara stego image yang dihasilkan dengan cover citra yang digunakan (Gouda, 2015).

Salah satu transformasi domain frekuensi yang diterapkan pada tugas studi ini adalah dengan penggunaan transformasi domain Discrete Cosine Transform (DCT) (Sharma \& Kumar, 2015). Discrete Cosine Transform (DCT) bukan merupakan teknik penyisipan, namun merupakan sarana atau teknik transformasi domain cover citra sebelum bit-bit pesan disisipkan. Teknik ini merupakan teknik transformasi yang mengubah sinyal dari representasi kawasan spasial ke dalam representasi kawasan frekuensi dengan memecah ukuran pixel cover citra kedalam blok-blok ukuran 8 × 8 pada fungsi sinyal cosinus.

Input proses transformasi domain $D C T$ yaitu cover citra berupa matriks dengan dimensi dua (2D) yaitu $\mathrm{m} \times \mathrm{n}$ maka, persamaan $D C T$ untuk setiap blok matriks ukuran $8 \times 8$ dituliskan pada Persamaan (1) sebagai berikut :

$$
s(u, v)=C(v) \sum_{y=0}^{m-1}\left[C(u) \sum_{x=0}^{n-1} s(x, y) \cos \frac{(2 x+1) u \pi}{2 n}\right] \cos \frac{(2 y+1) v \pi}{2 m}
$$

berikut persamaan Invers DCT untuk blok matrik berukuran $8 \times 8$ dalam mengembalikan nilai hasil transformasi domain $D C T$ kedalam nilai domain spasial kembali dituliskan pada Persamaan (2) sebagai berikut :

$$
s(x, y)=\sum_{y=0}^{m-1} \sum_{x=0}^{n-1} s(u, v) C(u) C(v) \cos \frac{(2 x+1) u \pi}{2 n} \cos \frac{(2 y+1) v \pi}{2 m}
$$

dimana;
a. $\mathrm{m}$ dan $\mathrm{n}$ adalah banyaknya kolom dan baris.
b. $u=0$ s.d. $m-1$ dan $v=0$ s.d. $n-1$.
c. $\mathrm{S}(\mathrm{u}, \mathrm{v})$ adalah pixel cover citra transformasi domain $D C T$
d. $\mathrm{S}(\mathrm{x}, \mathrm{y})$ adalah pixel cover citra domain spasial.
e. $C(u)=\sqrt{\frac{1}{n}}, u=0 ; \sqrt{\frac{2}{n}}, 1 \leq u \leq n-1$
f. $C(v)=\sqrt{\frac{1}{m}}, v=0 ; \sqrt{\frac{2}{m}}, 1 \leq v \leq m-1$
g. $\pi=180^{\circ}$

Setelah itu dilakukan kuantisasi dan dekuantisasi dari blok-blok matriks pixe/transformasi $D C T$ yang dihasilkan dengan ukuran 8 × 8 untuk menyisipan bit-bit pesan kedalam pixe/ transformasi DCT yang dihasilkan (Setyaningsih, 2015). Kuantisasi pada pixe/transformasi 
DCT diperlukan karena pixe/transformasi DCT yang dihasilkan tidak berbentuk bilangan bulat melainkan berbentuk bilangan desimal.

Nilai kuantisasi matriks pixe/transformasi DCT didapat dengan membagi setiap elemen dalam blok-blok matriks koefisien DCT dengan tabel matriks kuantisasi dan kemudian hasilnya dibulatkan ke dalam bilangan bulat terdekat. Pada Persamaan (3) dan (4) ditunjukan kuantisasi dan dekuantisasi, sedangkan ilustrasi kuantisasi dan dekuantisasi DCT block ditunjukan pada Gambar 1.

$$
\begin{aligned}
& s^{Q}(u, v)=\operatorname{round}\left(\frac{s(u, v)}{Q(u, v)}\right) \\
& s^{D}(u, v)=s(u, v) * Q(u, v) \\
& =\left[\begin{array}{rrrrrrrr}
162 & 40 & 20 & 72 & 30 & 2 & -1 & -1 \\
30 & 108 & 10 & 32 & 27 & 5 & 8 & -2 \\
.94 & -60 & 12 & -43 & -31 & 6 & -3 & 7 \\
.38 & -83 & -5 & -22 & 3 & 5 & -1 & 3 \\
-31 & 17 & -5 & -1 & 4 & -6 & 1 & -6 \\
0 & -1 & 2 & 0 & 2 & 2 & 8 & 2 \\
4 & -2 & 2 & 6 & 8 & -1 & 7 & 2 \\
-1 & 1 & 7 & 6 & 2 & 0 & 5 & 0
\end{array}\right] \\
& Q_{50}=\left[\begin{array}{rrrrrrrr}
16 & 11 & 10 & 16 & 24 & 40 & 51 & 61 \\
12 & 12 & 14 & 19 & 26 & 58 & 60 & 55 \\
14 & 13 & 16 & 24 & 40 & 57 & 69 & 56 \\
14 & 17 & 22 & 29 & 51 & 87 & 80 & 62 \\
18 & 22 & 37 & 56 & 68 & 109 & 103 & 77 \\
24 & 35 & 55 & 64 & 81 & 104 & 113 & 92 \\
49 & 64 & 78 & 87 & 103 & 121 & 120 & 101 \\
72 & 92 & 95 & 98 & 112 & 100 & 103 & 99
\end{array}\right] \\
& Q=\left[\begin{array}{cccccccc}
10 & 4 & 2 & 5 & 1 & 0 & 0 & 0 \\
3 & 9 & 1 & 2 & 1 & 0 & 0 & 0 \\
-7 & -5 & 1 & -2 & -1 & 0 & 0 & 0 \\
-3 & -5 & 0 & -1 & 0 & 0 & 0 & 0 \\
-2 & 1 & 0 & 0 & 0 & 0 & 0 & 0 \\
0 & 0 & 0 & 0 & 0 & 0 & 0 & 0 \\
0 & 0 & 0 & 0 & 0 & 0 & 0 & 0 \\
0 & 0 & 0 & 0 & 0 & 0 & 0 & 0
\end{array}\right] \\
& D=\left[\begin{array}{rrrrrrrr}
160 & 44 & 20 & 80 & 24 & 0 & 0 & 0 \\
36 & 108 & 14 & 38 & 26 & 0 & 0 & 0 \\
-98 & -65 & 16 & -48 & -40 & 0 & 0 & 0 \\
-42 & -85 & 0 & -29 & 0 & 0 & 0 & 0 \\
-36 & 22 & 0 & 0 & 0 & 0 & 0 & 0 \\
0 & 0 & 0 & 0 & 0 & 0 & 0 & 0 \\
0 & 0 & 0 & 0 & 0 & 0 & 0 & 0 \\
0 & 0 & 0 & 0 & 0 & 0 & 0 & 0
\end{array}\right]
\end{aligned}
$$

\section{Gambar 1. Ilustrasi Kuantisasi dan Dekuantisasi DCT}

Terakhir, dengan metode penyisipan menggunakan spread spectrum, konsep mendasar dari metode penyisipan ini adalah dengan menyisipkan sinyal informasi narrowband ke dalam noise wideband lalu menambahkan noise tersebut ke dalam cover image. Noise yang ditambahkan tersebut seperti noise yang terjadi pada saat proses akuisisi citra dan jika pada leve/ rendah, tidak akan mudah terdeteksi oleh indera penglihatan manusia maupun analisis komputer tanpa menggunakan citra aslinya.

Secara umum proses spread spectrum ini digambarkan pada Gambar 1. Pada sistem ini, pesan teks diubah ke dalam bentuk biner kemudian pesan dikalikan dengan pseudorandomnoise sehingga menghasilkan noise informasi sesuai (Bansal, 2014). Setelah itu noise informasi tersebut ditambahkan ke cover image dalam intensitas yang rendah agar tidak terdeteksi oleh mata manusia. Di sisi penerima, stego image diterima oleh penerima yang mempunyai kunci yang sama yaitu pseudorandom-noise yang sama untuk mengekstrak pesan yang diterima (M.P.S. Bhatia, 2014). 
Berkaitan dengan format object coveryang dapat digunakan dalam pertukaran informasi dunia digital saat ini, hampir semua file digital dapat dijadikan sebagai object cover dalam properti penggunaan metode steganografi. Kendati demikian, format yang paling cocok untuk dijadikan object cover digital adalah format file digital yang memiliki nilai redundancy bit yang tinggi. Redundancy bit adalah bit yang dapat dirubah tanpa merubah banyak karakteristik file secara keseluruhan (Massandy, 2017) (Negara, 2016).

\section{METODOLOGI PENELITIAN}

\subsection{Perancangan dan Pemodelan Sistem}

Perancangan sistem dijelaskan dengan diagram alir dibawah ini. Secara garis besar sistem tebagi menjadi beberapa proses. Pada Gambar 2 dan Gambar 3, ditunjukan proses penyisipan pesan (embbeding) dan proses ekstraksi pesan (retrieval) pada sistem.

\subsection{Pengujian sistem}

Pada stego image yang dihasilkan, selanjutnya akan dilakukan beberapa uji serangan yang bertujuan untuk mengetahui tingkat ketahanan sistem terhadap tindak perusakan yang terjadi pada proses implementasinya. Simulasi pengujian sistem dilakukan dengan pemberian serangan berupa gangguan noise, sebagai berikut :

\section{a. Noise Gaussian / White Noise}

Pada sebuah citra, noise ini menyebabkan citra berwarna putih. Banyak atau sedikitnya noise dipengaruhi oleh nilai rata-rata (mean) dan nilai variasi (variance) dalam skala 0 s.d. 1. Semakin besar mean dan variance maka citra hasil penambahan noise akan semakin mendekati warna putih. Pada simulasi pengujian ini dilakukan pengujian pada sistem dengan inensitas noise untuk mengetahui ketahanan citra pada stego image yang dihasilkan.

\section{b. Noise Salt and Pepper}

Pada sebuah citra, noise ini berupa titik-titik yang mirip seperti taburan garam dan lada. Pada citra RGB titik-titik (noise) tersebut berwarna red (merah), green (hijau) dan blue (biru). Titiktitik (noise) tersebut dipengaruhi oleh densitas (d) dalam skala 0 s.d. 1.

\subsection{Penilaian Objektif}

Penilaian objektif pada sistem adalah penilaian terkait dengan fakta matematis yang terukur. Penilaian objektif yang dilakukan pada sistem diantaranya adalah penilaian metode kriptografi dan metode steganografi sesuai dengan referensi yaitu Peak Signal Noise to Ratio (PSNR), Bit Error Rate (BER), Character Error Rate (CER), dan Signal Noise Ratio (SNR). 
Pengamanan Pesan pada Steganografi Citra dengan Teknik Penyisipan Spread Spectrum

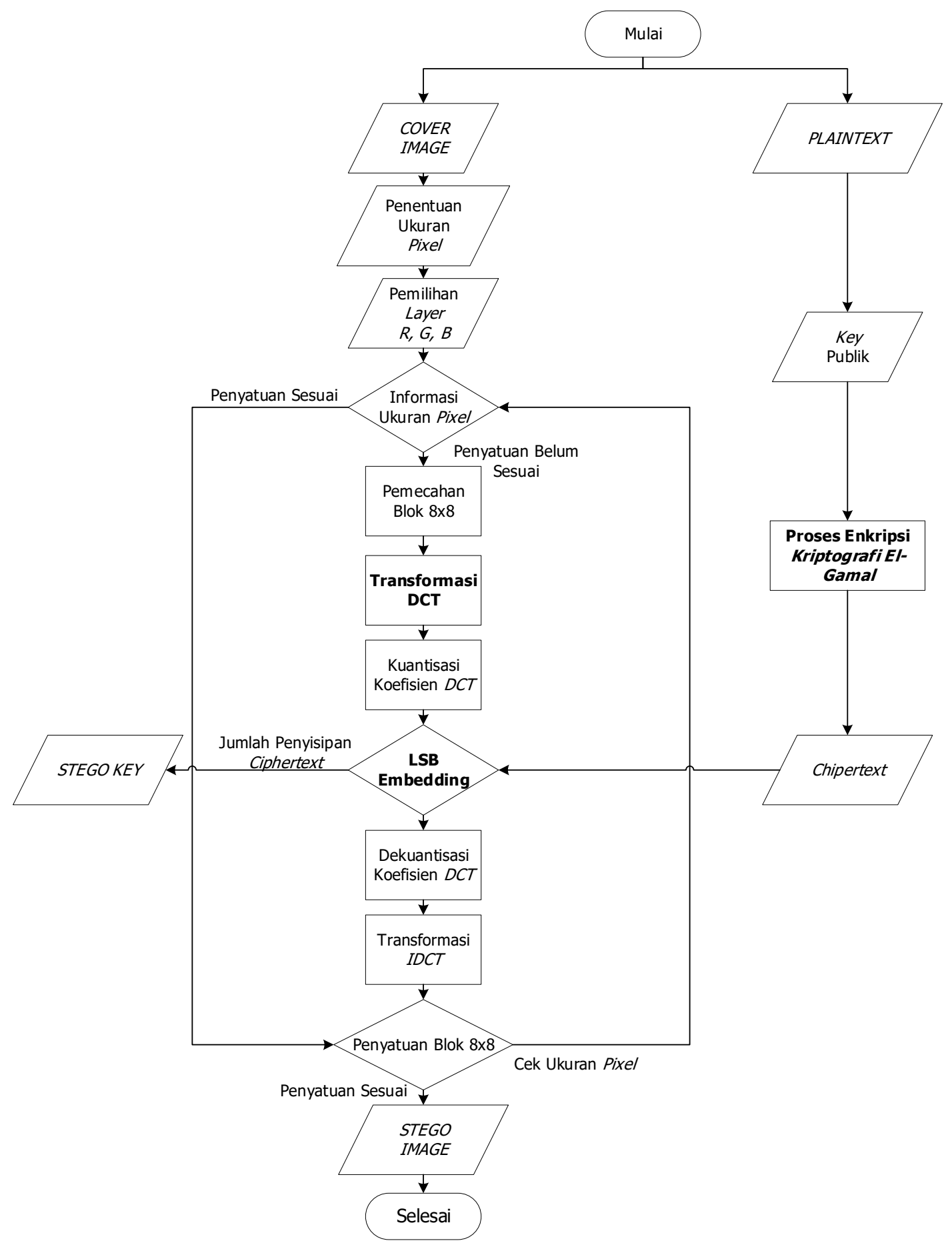

Gambar 2. Proses Penyisipan Pesan 
ELKOMIKA | ISSN (p): 2338-8323 | ISSN (e): 2459-9638

DOI : http://dx.doi.org/10.26760/elkomika.v7i3.544
| Vol. 7 | No. 3 | Halaman $544-558$

September 2019

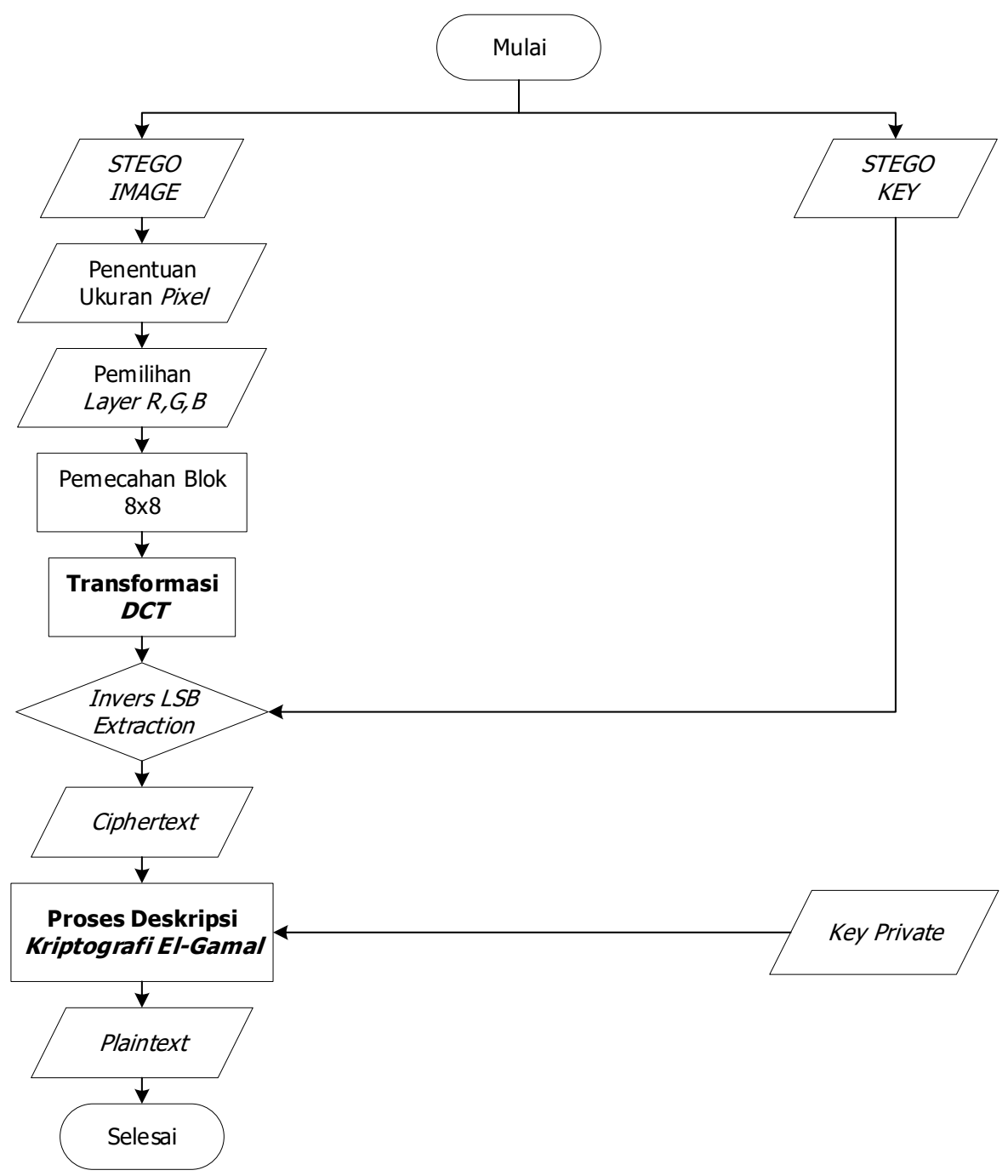

Gambar 3. Proses Ekstraksi Pesan

\section{HASIL PENGUJIAN DAN ANALISIS SISTEM}

\subsection{Cover Citra}

Penggunaan citra warna $(R G B)$ sebagai object cover dalam evaluasi skenario pengujian sistem menggunakan sebanyak tiga buah citra yang ditunjukan pada Gambar 4. Ukuran masingmasing cover citra yang digunakan berukuran 256 × 256, 512 × 512, dan 1024 x 1024 pixel. 


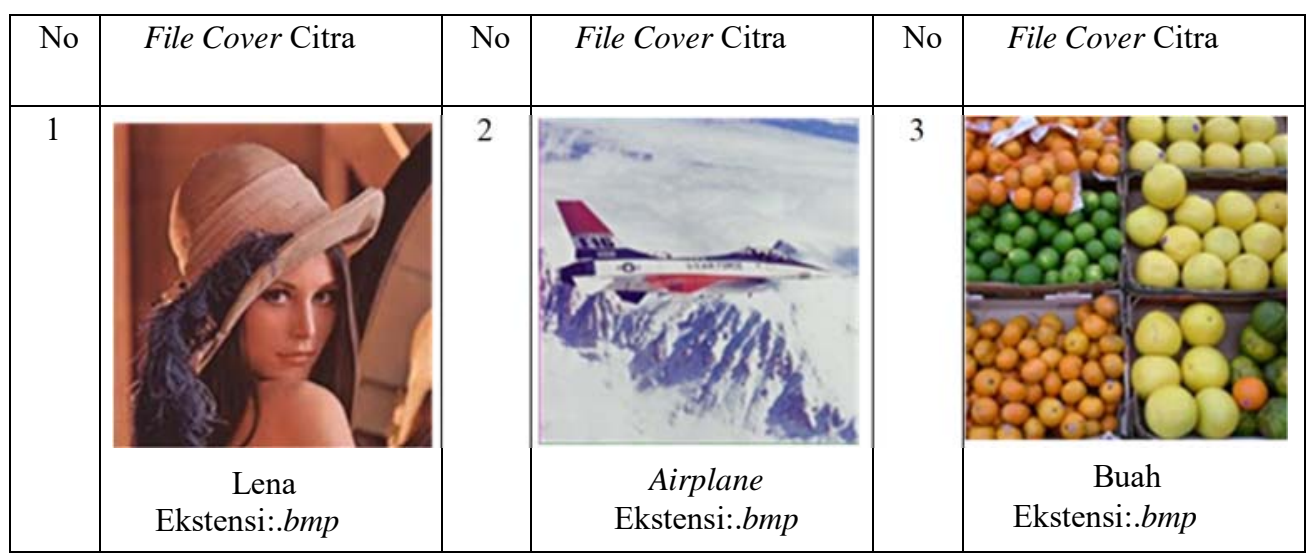

Gambar 4. Citra yang Digunakan

\subsection{Skenario Pengujian}

Pada skenario proses pengujian sistem, telah dilakukan beberapa skenario evaluasi pengujian, di antaranya sebagai berikut :

1. Skenario evaluasi kapasitas penyisipan cover citra citra terhadap jumlah karakter plaintext dan ciphertext.

2. Skenario evaluasi pemilihan layer warna pada cover citra.

3. Skenario evaluasi performansi sistem tanpa gangguan berupa noise meliputi penilaian PSNR, BER, CER, dan MOS, SNR.

4. Skenario evaluasi performansi sistem dengan gangguan noise meliputi penilaian $B E R$ dan $C E R$ terhadap akurasi pesan yang dapat diungkap atau ekstraksi.

\subsection{Pengujian Layer Warna Cover Citra}

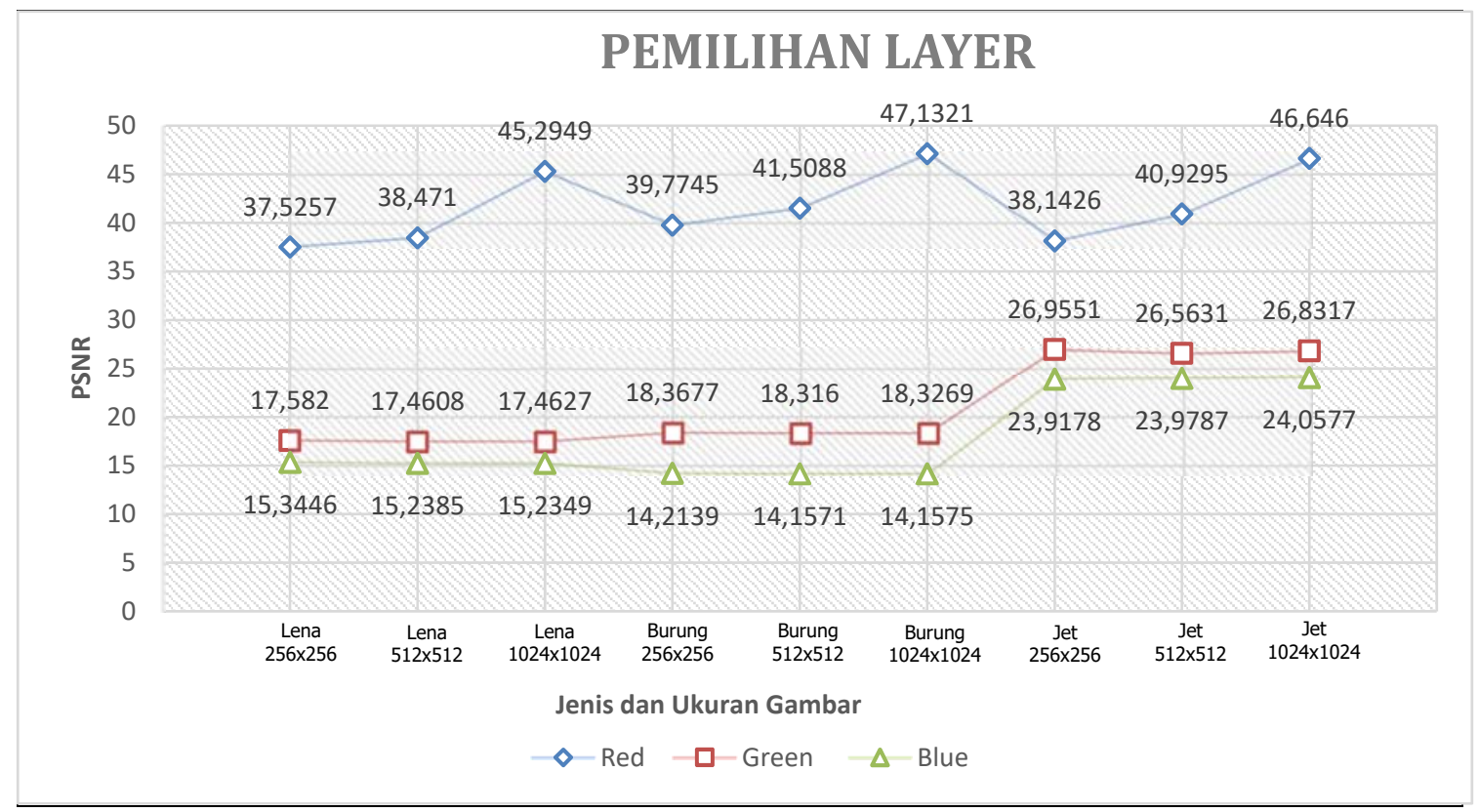

Gambar 5. Grafik Pemilihan Layer Warna 
Pemilihan layerwarna dalam sistem dilakukan untuk mengetahui layer warna terbaik pada tiga buah cover digunakan dalam proses penyisipan pesan berupa ciphertext berdasarkan penerapan metode steganografi. Terdapat tiga buah layerwarna yaitu Red Layer, Green Layer, dan Blue Layer pada cover citra warna $(R G B)$ yang diuji berdasakan penggunaan masingmasing nilai ukuran pixel cover citra yang di jelaskan pada Gambar 5.

\subsection{Pengujian Performansi Sistem Tanpa Gangguan Noise}

Pada pengujian performansi sistem, dilakukan pengujian dengan memilih tiga buah sample karakter pesan plaintext yang digunakan sebesar 21,42, dan 63 karakter. Pemilihan jumlah karakter yang digunakan dalam pengujian ini mengacu pada jumlah karakter maksimum kapasitas ukuran pixe/ 256 × 256 sebagaimana jumlah karakter pembanding terbesar di antara ukuran pixe/ uji lainnya dengan jumlah karakter plaintext sama dengan 64, dapat dilihat pada Tabel 1 - Tabel 6.

a. Citra ke-1: Lena

Tabel 1. Pengujian Performansi Objektif Citra Lena

\begin{tabular}{|c|c|c|c|c|c|c|c|}
\hline \multirow[t]{2}{*}{ No } & \multirow{2}{*}{$\begin{array}{c}\text { SKarakter } \\
\text { Uji } \\
\text { Plaintext }\end{array}$} & \multirow{2}{*}{$\begin{array}{c}\text { EKarakter } \\
\text { Uji Cipher } \\
\text { Text }\end{array}$} & \multirow{2}{*}{$\begin{array}{c}\text { Ukuran } \\
\text { Pixel Cover }\end{array}$} & \multicolumn{4}{|c|}{ Evaluasi Performansi Sistem } \\
\hline & & & & PSNR & BER & CER & SNR \\
\hline \multirow{3}{*}{1} & \multirow{3}{*}{21} & \multirow{3}{*}{42} & $256 \times 256$ & 36,69 & 0 & 0 & 45,75 \\
\hline & & & $512 \times 512$ & 38,52 & 0 & 0 & 40,64 \\
\hline & & & $1024 \times 1024$ & 45,36 & 0 & 0 & 34,86 \\
\hline \multirow{3}{*}{2} & \multirow{3}{*}{42} & \multirow{3}{*}{84} & $256 \times 256$ & 34,61 & 0 & 0 & 42,32 \\
\hline & & & $512 \times 512$ & 38,49 & 0 & 0 & 38,62 \\
\hline & & & $1024 \times 1024$ & 45,32 & 0 & 0 & 35,67 \\
\hline \multirow{3}{*}{3} & \multirow{3}{*}{63} & \multirow{3}{*}{126} & $256 \times 256$ & 35,53 & 0 & 0 & 42,55 \\
\hline & & & $512 \times 512$ & 38,47 & 0 & 0 & 36,78 \\
\hline & & & $1024 \times 1024$ & 45,29 & 0 & 0 & 31,24 \\
\hline
\end{tabular}

Tabel 2. Pengujian Performansi Subjektif Citra Lena

\begin{tabular}{|c|c|c|c|c|}
\hline No & $\begin{array}{l}\text { SKarakter } \\
\text { Uji Plain } \\
\text { text }\end{array}$ & $\begin{array}{l}\text { EKarakter } \\
\text { Uji Cipher } \\
\text { text }\end{array}$ & $\begin{array}{c}\text { Ukuran Pixel } \\
\text { Cover }\end{array}$ & $\begin{array}{c}\text { MOS } \\
\text { (Mean Opinion Score) } \\
n=30\end{array}$ \\
\hline \multirow{3}{*}{1} & \multirow{3}{*}{21} & \multirow{3}{*}{42} & $256 \times 256$ & 4,50 \\
\hline & & & $512 \times 512$ & 4,56 \\
\hline & & & $1024 \times 1024$ & 4,46 \\
\hline \multirow{3}{*}{2} & \multirow{3}{*}{42} & \multirow{3}{*}{84} & $256 \times 256$ & 4,43 \\
\hline & & & $512 \times 512$ & 4,48 \\
\hline & & & $1024 \times 1024$ & 4,50 \\
\hline \multirow{3}{*}{3} & \multirow{3}{*}{63} & \multirow{3}{*}{126} & $256 \times 256$ & 4,46 \\
\hline & & & $512 \times 512$ & 4,43 \\
\hline & & & $1024 \times 1024$ & 4,56 \\
\hline
\end{tabular}


b. Citra ke-2:Airplane

Tabel 3. Pengujian Performansi Objektif Citra Airplane

\begin{tabular}{|c|c|c|c|c|c|c|c|}
\hline \multirow[t]{2}{*}{ No } & \multirow{2}{*}{$\begin{array}{c}\text { SKarakter } \\
\text { Uji Plain } \\
\text { text }\end{array}$} & \multirow{2}{*}{$\begin{array}{c}\text { SKarakter } \\
\text { Uji Cipher } \\
\text { text }\end{array}$} & \multirow{2}{*}{$\begin{array}{c}\text { Ukuran } \\
\text { Pixel Cover }\end{array}$} & \multicolumn{4}{|c|}{ Evaluasi Performansi Sistem } \\
\hline & & & & PSNR & BER & CER & SNR \\
\hline \multirow{3}{*}{1} & \multirow{3}{*}{21} & \multirow{3}{*}{42} & $256 \times 256$ & 35,34 & 0 & 0 & 46,54 \\
\hline & & & $512 \times 512$ & 41,06 & 0 & 0 & 40,17 \\
\hline & & & $1024 \times 1024$ & 46,73 & 0 & 0 & 36,06 \\
\hline \multirow{3}{*}{2} & \multirow{3}{*}{42} & \multirow{3}{*}{84} & $256 \times 256$ & 35,24 & 0 & 0 & 48,28 \\
\hline & & & $512 \times 512$ & 40,97 & 0 & 0 & 43,74 \\
\hline & & & $1024 \times 1024$ & 46,69 & 0 & 0 & 38,05 \\
\hline \multirow{3}{*}{3} & \multirow{3}{*}{63} & \multirow{3}{*}{126} & $256 \times 256$ & 35,15 & 0 & 0 & 46,77 \\
\hline & & & $512 \times 512$ & 40,93 & 0 & 0 & 41,66 \\
\hline & & & $1024 \times 1024$ & 46,64 & 0 & 0 & 35,88 \\
\hline
\end{tabular}

Tabel 4. Pengujian Performansi Subjektif Citra Airplane

\begin{tabular}{|c|c|c|c|c|}
\hline No & $\begin{array}{c}\text { EKarakter } \\
\text { Uji } \\
\text { Plaintext }\end{array}$ & $\begin{array}{l}\text { SKarakter } \\
\text { Uji Cipher } \\
\text { Text }\end{array}$ & $\begin{array}{c}\text { Ukuran Pixel } \\
\text { Cover }\end{array}$ & $\begin{array}{c}\text { MOS } \\
\text { (Mean Opinion Score) } \\
n=30\end{array}$ \\
\hline \multirow{3}{*}{1} & \multirow{3}{*}{21} & \multirow{3}{*}{42} & $256 \times 256$ & 4,33 \\
\hline & & & $512 \times 512$ & 4,40 \\
\hline & & & $1024 \times 1024$ & 4,50 \\
\hline \multirow{3}{*}{2} & \multirow{3}{*}{42} & \multirow{3}{*}{84} & $256 \times 256$ & 4,36 \\
\hline & & & $512 \times 512$ & 4,43 \\
\hline & & & $1024 \times 1024$ & 4,56 \\
\hline \multirow{3}{*}{3} & \multirow{3}{*}{63} & \multirow{3}{*}{126} & $256 \times 256$ & 4,44 \\
\hline & & & $512 \times 512$ & 4,46 \\
\hline & & & $1024 \times 1024$ & 4,63 \\
\hline
\end{tabular}

c. Citra ke-3:Buah

Tabel 5. Pengujian Performansi Objektif Citra Buah

\begin{tabular}{|c|c|c|c|c|c|c|c|}
\hline \multirow[t]{2}{*}{ No } & \multirow{2}{*}{$\begin{array}{c}\text { ¿Karakter } \\
\text { Uji } \\
\text { Plaintext }\end{array}$} & \multirow{2}{*}{$\begin{array}{c}\text { EKarakter } \\
\text { Uji Cipher } \\
\text { Text }\end{array}$} & \multirow{2}{*}{$\begin{array}{c}\text { Ukuran } \\
\text { Pixel Cover }\end{array}$} & \multicolumn{4}{|c|}{ Evaluasi Performansi Sistem } \\
\hline & & & & PSNR & BER & CER & SNR \\
\hline \multirow{3}{*}{1} & \multirow{3}{*}{21} & \multirow{3}{*}{42} & $256 \times 256$ & 36,87 & 0 & 0 & 46,54 \\
\hline & & & $512 \times 512$ & 38,91 & 0 & 0 & 40,17 \\
\hline & & & $1024 \times 1024$ & 45,59 & 0 & 0 & 36,06 \\
\hline \multirow{3}{*}{2} & \multirow{3}{*}{42} & \multirow{3}{*}{84} & $256 \times 256$ & 36,79 & 0 & 0 & 48,28 \\
\hline & & & $512 \times 512$ & 38,87 & 0 & 0 & 43,74 \\
\hline & & & $1024 \times 1024$ & 45,56 & 0 & 0 & 38,05 \\
\hline \multirow{3}{*}{3} & \multirow{3}{*}{31} & \multirow{3}{*}{126} & $256 \times 256$ & 36,79 & 0 & 0 & 46,77 \\
\hline & & & $512 \times 512$ & 38,84 & 0 & 0 & 41,66 \\
\hline & & & $1024 \times 1024$ & 45,52 & 0 & 0 & 35,88 \\
\hline
\end{tabular}


Tabel 6. Pengujian Performansi Subjektif Citra Buah

\begin{tabular}{|c|c|c|c|c|}
\hline No & $\begin{array}{c}\text { ¿Karakter } \\
\text { Uji } \\
\text { Plaintext }\end{array}$ & $\begin{array}{c}\text { EKarakter } \\
\text { Uji } \\
\text { Ciphertext }\end{array}$ & $\begin{array}{c}\text { Ukuran Pixel } \\
\text { Cover }\end{array}$ & $\begin{array}{c}\text { MOS } \\
\text { (Mean Opinion Score) } \\
\mathrm{n}=30\end{array}$ \\
\hline \multirow{3}{*}{1} & \multirow{3}{*}{21} & \multirow{3}{*}{42} & $256 \times 256$ & 4,46 \\
\hline & & & $512 \times 512$ & 4,50 \\
\hline & & & $1024 \times 1024$ & 4,60 \\
\hline \multirow{3}{*}{2} & \multirow{3}{*}{42} & \multirow{3}{*}{84} & $256 \times 256$ & 4,56 \\
\hline & & & $512 \times 512$ & 4,50 \\
\hline & & & $1024 \times 1024$ & 4,56 \\
\hline \multirow{3}{*}{3} & \multirow{3}{*}{63} & \multirow{3}{*}{126} & $256 \times 256$ & 4,60 \\
\hline & & & $512 \times 512$ & 4,50 \\
\hline & & & $1024 \times 1024$ & 4,70 \\
\hline
\end{tabular}

Dalam hasil analisis evaluasi penilaian objektif terhadap nilai $B E R$ dan $C E R$ yang dihasilkan oleh stegoimage tanpa diberikan gangguan yang digunakan maka, dinyatakan ketiga buah stegoimage memiliki nilai $B E R$ dan $C E R$ yang sangat baik dengan hasil nilai performansi sebesar 0 untuk semua pengujian yang telah dilakukan, ditunjukan pada Tabel 1, Tabel 3, dan Tabel 6. Perolehan nilai evaluasi performansi $B E R$ dan $C E R$ menandakan bahwa tidak ada bit maupun karakter pesan yang hilang maupun berubah atau error ketika dilakukan proses ekstraksi atau pengungkapan pesan pada stego image yang dihasilkan.

Pada Gambar 6 ditunjukan grafik nilai PSNR yang dihasilkan oleh ketiga stego image. Studi ini membuktikan grafik hubungan antara jumlah karakter ciphertext yang disisipkan terhadap ukuran pixel cover citra menunjukan bahwa nilai PSNR pada stego image akan menghasilkan nilai yang baik atau tinggi apabila ukuran pixe/ cover citra yang digunakan berukuran besar karena ukuran pixe/ menambahkan ruang bagi stego image. Pengaruh perbedaan jumlah karakter ciphertext yang disisipkan pada setiap ukuran pixe/ yang sama akan menyebabkan penurunan nilai PSNR pada stego image yang dihasilkan. Adapun penilaian MOS yang dihasilkan ditunjukan pada Gambar 7.

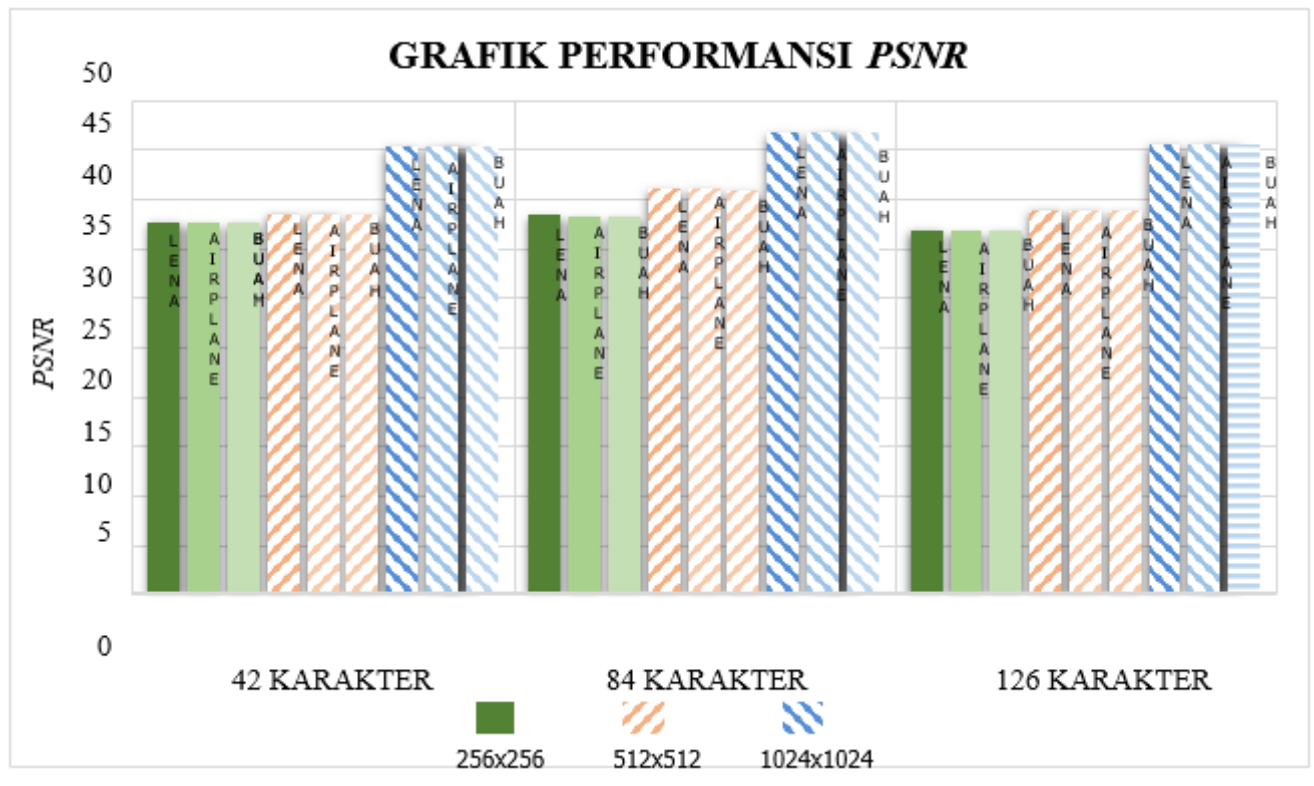

Gambar 6. Grafik Performansi PSNR 
Pada Gambar 7, penilaian MOS yang dihasilkan dari penilaian sebanyak 30 responden menghasilkan nilai rata-rata sebesar 4,5. Dalam kriteria penilaian MOS yang dihasilkan maka, dapat dinyatakan bahwa pada studi ini menunjukan perbandingan kualitas antara stego image dengan cover citra tergolongakan membesar ketika ukuran pixe/bertambah.

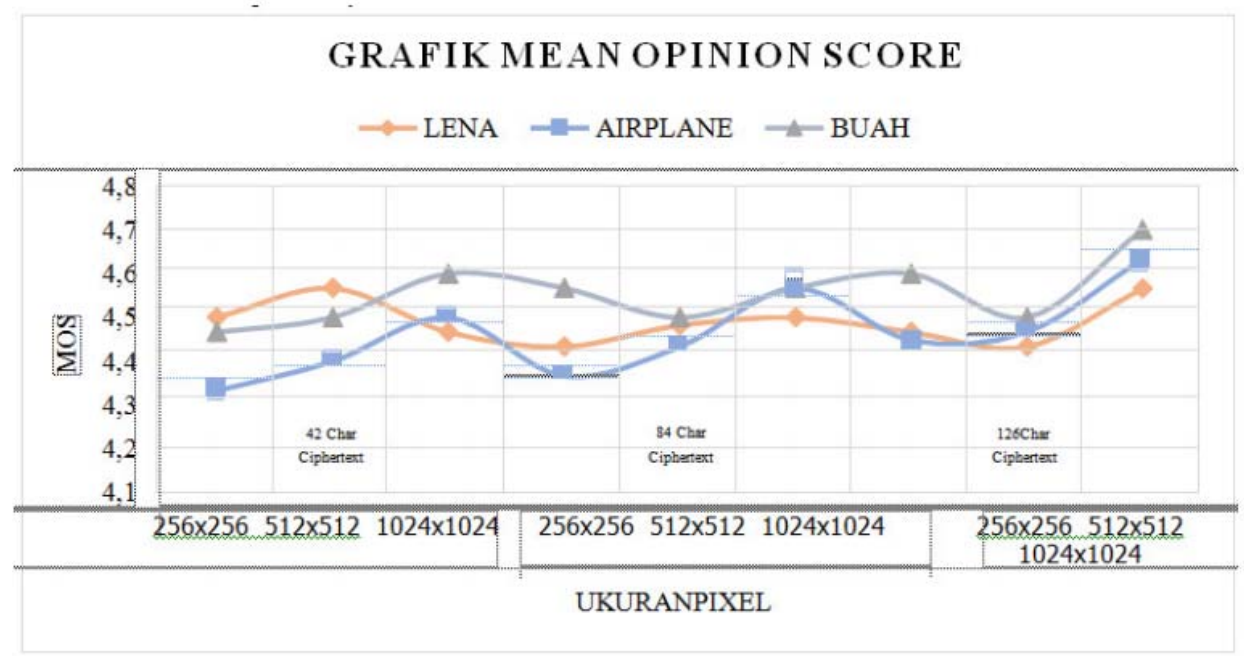

Gambar 7. Grafik Performansi MOS

\subsection{Pengujian Performansi Sistem Dengan Gangguan Noise}

Pada pengujian performansi sistem, telah dilakukan beberapa pengujian gangguan diantaranya adalah Noise Gaussian dan Noise Salt \& Pepper. Pengujian performansi dengan pemberian noise pada sistem dilakukan sebagai analisa hasil evaluasi ketahanan plaintext yang dapat terungkap dari analisa nilai performansi $B E R$ dan $C E R$ yang dihasilkan. Dalam skenario pengujian performansi sistem dengan gangguan noise, pengujian dilakukan pada cover citra Lena dengan penentuan jumlah karakter penyisipan terhadap ukuran pixe/ yang digunakan sebagai data uji pengujian.

\section{a. Noise Gaussian}

Pada pengujian performansi terkait gangguan Noise Gaussian pada stego image, dilakukan pemilihan beberapa nilaivarians dari rentang 0 s.d. 1 . Pada Tabel 7 pengujian dilakukan sebanyak nilai rata-rata tiga kali percobaan untuk setiap ukuran pixel. Pada pengujian keberhasilan dan ketahanan stego image dalam mengungkapkan atau melakukan ekstraksi pesan dengan pemberian uji gangguan Noise Gaussian, maka dihasilkan evaluasi pada Tabel 7 yang menunjukan bahwa, nilai varians yang digunakan terkait gangguan Noise Gaussian akan merusak ketahanan dan pengungkapan pesan tersembunyi pada nilai varians sebesar 0,0006. Nilai variansmaksimum yang dapat ditoleransi terkait keberhasilan dalam pengungkapan pesan dalam pemberian Noise Gaussian diperoleh dengan nilai varians sebesar $\pm 0,0001$. Hal ini membuktikan studi ini menghasilkan BER dan CER yang kecil jika terdapat gangguan Noise Gaussian. 
Tabel 7. Pengujian Noise Gaussian

\begin{tabular}{|c|c|c|c|c|c|c|c|}
\hline \multirow{3}{*}{ No } & \multirow{3}{*}{ Ukuran Pixel } & \multicolumn{6}{|c|}{$\begin{array}{c}\text { Evaluasi Performansi Noise Gaussian } 42 \\
\text { Karakter Cipher text }\end{array}$} \\
\hline & & \multicolumn{2}{|r|}{0,0001} & \multicolumn{2}{|c|}{0,0003} & \multicolumn{2}{|c|}{0,0006} \\
\hline & & BER & CER & BER & CER & BER & CER \\
\hline 1 & $256 \times 256$ & 0 & 0 & 0,22 & 0,53 & 0,36 & 1 \\
\hline 2. & $512 \times 512$ & 0 & 0 & 0,25 & 0,69 & 0,38 & 1 \\
\hline 3. & $1024 \times 1024$ & 0 & 0 & 0,25 & 0,71 & 0,39 & 1 \\
\hline \multirow{3}{*}{ No. } & \multirow{3}{*}{ Ukuran Pixel } & \multicolumn{6}{|c|}{$\begin{array}{c}\text { si Performansi Noise Gaussian } 84 \text { Karakter Cipher } \\
\text { text }\end{array}$} \\
\hline & & \multicolumn{2}{|r|}{0,0001} & \multicolumn{2}{|c|}{0,0003} & \multicolumn{2}{|c|}{0,0006} \\
\hline & & BER & CER & BER & CER & BER & CER \\
\hline 1. & $256 \times 256$ & 0 & 0 & 0,24 & 0,59 & 0,39 & 1 \\
\hline 2. & $512 \times 512$ & 0 & 0 & 0,24 & 0,61 & 0,40 & 1 \\
\hline 3. & $1024 \times 1024$ & 0 & 0 & 0,24 & 0,66 & 0,41 & 1 \\
\hline \multirow{3}{*}{ No. } & \multirow{3}{*}{ Ukuran Pixel } & \multicolumn{6}{|c|}{$\begin{array}{c}\text { i Performansi Noise Gaussian } 126 \text { Karakter Cipher } \\
\text { text }\end{array}$} \\
\hline & & \multicolumn{2}{|r|}{0,0001} & \multicolumn{2}{|c|}{0,0003} & \multicolumn{2}{|c|}{0,0006} \\
\hline & & BER & CER & BER & CER & BER & CER \\
\hline 1 & $256 \times 256$ & 0 & 0 & 0,24 & 0,64 & 0,40 & 1 \\
\hline 2. & $512 \times 512$ & 0 & 0 & 0,26 & 0,65 & 0,40 & 1 \\
\hline 3. & $1024 \times 1024$ & 0 & 0 & 0,27 & 0,66 & 0,43 & 1 \\
\hline
\end{tabular}

Tabel 8. Pengujian Noise Salt \& Pepper

\begin{tabular}{|c|c|c|c|c|c|c|c|}
\hline \multirow{3}{*}{ No. } & \multirow{3}{*}{$\begin{array}{c}\text { Ukuran } \\
\text { Pixel }\end{array}$} & \multicolumn{6}{|c|}{$\begin{array}{c}\text { Evaluasi Performansi Noise Salt \& Pepper } 42 \\
\text { KarakterCiphertext }\end{array}$} \\
\hline & & \multicolumn{2}{|r|}{0,0001} & \multicolumn{2}{|c|}{0,001} & \multicolumn{2}{|c|}{0,01} \\
\hline & & BER & CER & BER & CER & BER & CER \\
\hline 1 & $256 \times 256$ & 0 & 0 & 0,158 & 0,426 & 0,406 & 1 \\
\hline 2. & $512 \times 512$ & 0,005 & 0,031 & 0,208 & 0,507 & 0,404 & 1 \\
\hline 3. & $1024 \times 1024$ & 0,011 & 0,047 & 0,226 & 0,571 & 0,450 & 1 \\
\hline \multirow{3}{*}{ No. } & \multirow{3}{*}{$\begin{array}{l}\text { Ukuran } \\
\text { Pixel }\end{array}$} & \multicolumn{6}{|c|}{$\begin{array}{c}\text { Evaluasi Performansi Noise Salt \& Pepper } 84 \\
\text { KarakterCiphertext }\end{array}$} \\
\hline & & \multicolumn{2}{|r|}{0,0001} & \multicolumn{2}{|c|}{0,001} & \multicolumn{2}{|c|}{0,01} \\
\hline & & BER & CER & BER & CER & BER & CER \\
\hline 1 & $256 \times 256$ & 0,002 & 0,015 & 0,164 & 0,428 & 0,423 & 1 \\
\hline 2. & $512 \times 512$ & 0,010 & 0,023 & 0,226 & 0,531 & 0,453 & 1 \\
\hline 3. & $1024 \times 1024$ & 0,023 & 0,079 & 0,232 & 0,583 & 0,461 & 1 \\
\hline \multirow{3}{*}{ No. } & \multirow{3}{*}{$\begin{array}{l}\text { Ukuran } \\
\text { Pixel }\end{array}$} & \multicolumn{6}{|c|}{$\begin{array}{c}\text { Evaluasi Performansi Noise Salt \& Pepper } 126 \\
\text { KarakterCiphertext }\end{array}$} \\
\hline & & \multicolumn{2}{|r|}{0,0001} & \multicolumn{2}{|c|}{0,001} & \multicolumn{2}{|c|}{0,01} \\
\hline & & BER & CER & BER & CER & BER & CER \\
\hline 1 & $256 \times 256$ & 0,007 & 0,015 & 0,154 & 0,455 & 0,427 & 1 \\
\hline 2. & $512 \times 512$ & 0,171 & 0,052 & 0,202 & 0,545 & 0,450 & 1 \\
\hline 3. & $1024 \times 1024$ & 0,029 & 0,079 & 0,202 & 0,587 & 0,480 & 1 \\
\hline
\end{tabular}




\section{b. Noise Salt \& Pepper}

Pada pengujian performansi terkait gangguan Noise Salt \& Pepper, dilakukan pemilihan beberapa nilai density dari rentang 0 s.d. 1. Pada Tabel 8 pengujian dilakukan sebanyak nilai rata-rata tiga kali percobaan untuk setiap ukuran pixel. Pengujian dalam keberhasilan pengungkapan pesan terkait dengan pemberian gangguan terhadap stego image berupa Noise Salt \& Pepper pada Tabel 8 maka, studi ini menunjukkan bahwa dengan nilai density yang digunakan bernilai sama dengan atau lebih dari nilai 0,01 dari rentang 0 sampai dengan 1 maka dapat didapatkan hasil bahwa ketahanan pengungkapan pesan tersembunyi dalam stego image akan rusak seluruhnya atau rusak $100 \%$. Sistem dapat mengungkapkan atau melakukan ekstraksi dengan nilai maksimum toleransi density sebesar $\pm 0,0001$. Nilai tersebut merupakan nilai yang dapat ditoleransi oleh sistem berdasarkan gangguan yang diberikan berupa Noise Salt \& Pepper.

\section{KESIMPULAN}

Dalam upaya meningkatkan keamanan pengiriman informasi atau pesan dalam dunia digital, pada tugas akhir ini telah berhasil diselesaikan implementasi dari sebuah system. Pengamanan pesan pada steganografi citra domain Discrete Cosine Transform dengan teknik penyisipan Spread Spectrum memberikan variasi keamanan. Terkait dengan penerapan metode dan teknik yang digunakan dalam implementasi sistem, dihasilkan kualitas stego image yang sangat mirip dengan cover citra yang digunakan di lihat dari perolehan nilai performansi objektif PSNR diatas $30 \mathrm{~dB}$ dan subjektif MOS di atas nilai 4. Terkait dengan pengujian Noise Gaussian dan Noise Salt \& Pepper yang dilakukan, sistem akan mentoleransi nilai density maupun nilai varians maksimum yang diberikan sebesar $\pm 0,0001$.

\section{DAFTAR RUJUKAN}

Alfian Zakaria, R. M. (2015). Steganografi Citra Digita/Menggunakan Teknik Discrete Wavelet Transform pada Ruang Warna CIELab. ITB.

Bansal, D. (2014). An Improved DCT based Steganography Technique. International Journal of Computer Applications, 102(14), 46-49.

Chudasama, J. M. (2016). Dual Steganography: A New Hiding Technique for Digital Communication. International Journal of Advanced Research in Electrical, Electronoc and Instrumentation Engineering, 3184-3188.

Gouda, S. (2015). Least Significant Bit (LSB) and Discrete Cosine Transform (DCT) based Steganography. International Journal of Emerging Trending Engineering and Basic Science (IJEEBS), 2(1), 31-36.

Gunjal, M., \& Jha, J. (2014). Image Steganography Using Discrete Cosine Transform (DCT) and Blowfish Algorithm. International Journal of Computer Trends and Technology (IJCTT), 11(4), 144-150.

H., H., B, G., \& N, L. (2017). Implementasi Teknik Watermarking menggunakan FFT dan Spread Spectrum Watermark pada Data Audio Digital. ELKOMNIKA, 4(1), 98-109. 
M.P.S. Bhatia, S. K. (2014). An Image Steganography Method Using Spread Spectrum Technique. Proceedings of Fourth International Conference on Soft Computing for Problem Solving (pp. 219-236). New Delhi: Springer India.

Massandy, D. T. (2017). Algoritma Elgamal Dalam Pengamanan Pesan Rahasia. Makalah Strukdis 0910-056.

Negara, I. K. (2016). Analisis dan Implementasi Gabungan Kriptografi Elgamal dan Steganografi Frame Dengan Menggunakan Kunci Citra Digital. Jurnal Eksplora Informatika, 141-150.

Neil F. Johnson, S. J. (2001). Information Hiding: Steganography and Watermarking-Attacks and Countermeasures: Steganography and Watermarking - Attacks and Countermeasures. London: Kluwer Academic Publishing.

ITB, S. (2014, 10 02). Summit, Seminar Nasional Indonesia Cyber Crime. Dipetik 2 5, 2017, dari STEI ITB Website: http://stei.itb.ac.id/id/blog/2014/10/03/indonesia-cyber-crimesummit-iccs-2014/

Setyaningsih, M. (2015). Kriptografi \& Implementasinya menggunakan MATLAB. Yogyakarta: Penerbit ANDI Yogakarta.

Sharma, S., \& Kumar, U. (2015). Review of Transform Domain Techniques for Image Steganography. 3(5), 2013-2016. 